\title{
Research on the Cultivation of Professional Quality of Female College Students Majoring in Flight Attendants
}

\author{
Peng Zhang ${ }^{1}$ \\ ${ }^{1}$ Tourism School, Shandong Women's University, Jinan, China \\ Correspondence: Peng Zhang, Tourism School, Shandong Women's University, Jinan 250300, Shandong, China. \\ E-mail: 200899654@qq.com
}

Received: November 15, 2021

Accepted: December 17, 2021

Online Published: December 23, 2021

doi:10.20849/aes.v6i2.970

URL: https://doi.org/10.20849/aes.v6i2.970

\begin{abstract}
Recently, there has been no uniform evaluation standard for the professional quality of female college students majoring in flight attendants. And there are many problems in the professional quality training process of female college students due to the uneven quality and training system of various universities. In view of this situation, this paper has conducted investigations, constructed a professional quality evaluation index system for female flight attendants, analyzed the problems in the training of professional quality, and put forward suggestions for the training of professional quality of female college students in flight attendants, hoping to be able to help Provide reference for training talents in universities.
\end{abstract}

Keywords: flight attendant major, female college students, professional quality

\section{Introduction}

In recent years, the scale of the civil aviation transportation industry has been continuously expanded, the service capacity of the industry has been gradually improved. As of the end of the year 2019, there were 68 airlines and a fleet of 3,818 aircraft. With the rapid development of the civil aviation transportation industry, the industry's demand for flight attendants has also increased. This demand is not only reflected in the increase in number, but also in the improvement of professional quality.

The Civil Aviation Administration of China announced in 2019 that the gender ratio of flight attendants is 1:3, that is, the number of female flight attendants is approximately three times that of male flight attendants. That means female is the absolute main body of the flight attendant position. Through reference search, it is found that the current research on this subject has not paid attention to gender differences and the professional quality training of students from the perspective of gender differences. Therefore, this paper selects female college students majoring in flight attendants as the research object.

There are currently no less than 300 schools offering flight attendant majors in the country. However, due to the differences in talent training programs, teaching quality and talent training orientation of each school, the overall quality of the trained flight attendant students is also uneven. The result of this paper could promote the students to meet the requirements of civil aviation transportation companies, constructing the professional quality evaluation model of the flight attendant majors and exploring the path of professional quality education.

\section{The Composition of Professional Quality of Female College Students Majoring in Flight Attendants}

\subsection{Related Theories of Professional Quality}

The concept of professional quality is relatively broad. It is a comprehensive manifestation of practitioners' cognition and adaptability to social occupations, and is the comprehensive quality of practitioners in the professional process. Based on the perspectives of other researchers, this paper summarizes the concept of professional quality as follows: professional quality is the sum of the elements that social individuals should have, under the existing psychological and physiological foundation conditions, by self-study, acquired education and practice. From the content, professional quality can include many aspects such as psychology and morality, values, knowledge, body, ability and attitude, etc.

From the perspective of the constitutional dimensions of professional quality, this paper, based on the perspectives of predecessors, believes that professional quality can be divided into five dimensions, namely as 
follows. Professional moral quality mainly refers to the professional ethics and emotions and professional values possessed by different professional individuals. Basic professional quality refers to the basic qualities that should be possessed, including certain basic cultural qualities, psychology quality and physical fitness, etc. General professional quality refers to general skills that different individuals should have in their careers, such as self-learning ability and teamwork awareness, communication, information technology application, management, etc. Vocational professional quality refers to the knowledge and skills that are closely related to the profession and professional skills that individuals in different occupations should have when they are engaged in the profession. Developmental professional quality puts forward certain requirements for different professional individuals, referring to the qualities of continuous learning, active innovation and entrepreneurship that an individual should possess.

\subsection{Analysis of the Professional Quality System of Female College Students Majoring in Flight Attendants}

In order to make the composition of the professional quality of female undergraduates majoring in flight attendant, this paper conducted interviews with human resources of 10 representative airlines and learned more about the training items, courses and requirements for the quality of employees at work of these airlines in the induction training for new flight attendants. At the same time, this paper also conducted interviews with 30 female college students majoring in flight attendants who have graduated, and investigate their views about professional quality and the requirements of flight attendants. Integrating the results of the survey and statistics, this paper has formulated a system table for the professional quality of female college students majoring in flight attendants (see Table 1).

Table 1. Professional quality system of female college students majoring in flight attendants

\begin{tabular}{|c|c|c|}
\hline $\begin{array}{l}\text { Professional Quality } \\
\text { Dimension }\end{array}$ & First-level Index & Second-level Index \\
\hline \multirow{5}{*}{ Professional Moral Quality } & \multirow{2}{*}{ Ideological \& Political Quality } & Political Attitude \& Position \\
\hline & & Political Theory Level \\
\hline & \multirow{3}{*}{ Professional Ethics } & Professional Self-identity \\
\hline & & Professional Ethics \\
\hline & & $\begin{array}{c}\text { Sense of Responsibility \& Professional } \\
\text { Dedication }\end{array}$ \\
\hline \multirow{7}{*}{ Basic Professional Quality } & \multirow{2}{*}{ Language Quality } & Language Application Skills \\
\hline & & Foreign Language Service Ability \\
\hline & \multirow{2}{*}{ Legal \& Safety Awareness } & Occupational Safety Awareness \\
\hline & & Legal Awareness \\
\hline & \multirow{3}{*}{$\begin{array}{c}\text { Physical \& Psychological } \\
\text { Qualities }\end{array}$} & Emotional Work Ability \\
\hline & & $\begin{array}{c}\text { Resistance to Stress \& Psychological } \\
\text { Adjustment Ability }\end{array}$ \\
\hline & & Occupational Safety \& Physical Fitness \\
\hline \multirow{7}{*}{ General Professional Quality } & \multirow{2}{*}{$\begin{array}{l}\text { Communication \& } \\
\text { Interpersonal Skills }\end{array}$} & Communication Skills \\
\hline & & Social Interpersonal Competence \\
\hline & \multirow{3}{*}{ Cooperation \& Collaboration } & Team Work \\
\hline & & Problem Solving \& Adaptability \\
\hline & & Execution Ability \\
\hline & \multirow{2}{*}{ Self-discipline } & Self-learning Ability \\
\hline & & Self-management \& discipline \\
\hline \multirow{7}{*}{$\begin{array}{l}\text { Vocational Professional } \\
\text { Quality }\end{array}$} & \multirow{3}{*}{ Professional Knowledge } & Basic Theory Course Study \\
\hline & & Professional Course Study \\
\hline & & Related Knowledge Study \\
\hline & \multirow{2}{*}{ Vocational Skills } & Job skills \\
\hline & & Handle Official Business \\
\hline & \multirow{2}{*}{ Etiquette \& Occupational Image } & Etiquette \& Civility \\
\hline & & Occupational Image Building \\
\hline \multirow{2}{*}{$\begin{array}{c}\text { Developmental Professional } \\
\text { Quality }\end{array}$} & Innovation Capacity & \\
\hline & Career Planning Ability & \\
\hline
\end{tabular}




\section{Problems of Professional Quality Training for Female College Students Majoring in Flight Attendants}

Although colleges and universities can basically cultivate the professional qualities of college students, there are still problems in the training process. The most obvious problem is that in the process of cultivating professional quality, the gender difference between male and female students and the difference in the job content are ignored. These problems are mainly embodied in the dimensions of professional moral quality, basic professional quality, general professional quality and development professional quality.

\subsection{Problems in the Cultivation of Professional Moral Quality}

\subsubsection{Low Professional Identity}

There are two typical stereotypes on the flight attendant occupation. One thinks the job engages elegant image and good income; the other thinks that the job is just a waitress working in the air. Many college students are influenced by the second viewpoint and believe that they are discriminated, especially when treated impolitely by passengers, which reduce their sense of identity with the occupation of flight attendant. Women are more likely to be discriminated by others, thus affects loyalty and motivation.

\subsubsection{Lack of Professional Dedication}

Professional dedication is a necessary quality to produce job performance. In the survey, many airlines stated that flight attendants often complained and were not enthusiastic about their work. In the process of quality cultivation, colleges only notice theory education but lack of practice. Many families are also affected by social concepts such as "more money should be spent in girls' grow-up", which causes the girls couldn't bear hard work, which is also the reason of lack of professional dedication.

\subsection{Problems in Basic Professional Quality Training}

\subsubsection{Lack of Occupational Safety Education}

Occupational safety involves various hazards that practitioners may face in their work, such as equipment operations, emergencies, etc. These issues are rarely involved in the courses, and not enough even if they are involved. Occupational safety also involves workplace bullying and sexual harassment, which is particularly common for female. All female college students surveyed stated that within first year of their employment, they were often subjected to workplace bullying from their superiors and levels of sexual harassment from travelers and colleagues. which often bring heavy mental pressure to them.

\subsubsection{Neglect the Cultivation of Physical and Mental Quality}

As a typical service occupation, flight attendants have higher requirements for physical and mental quality at work. Flight attendants have to pay physical energy in their work and also need to use their brains to solve problems and complete customer service. High-intensity work requires better physical fitness. Compared with men, women have less physical strength and are more prone to fatigue during work. In addition, air services also require emotional work, that is, flight attendants need to pay a certain amount of emotions to meet the requirements of the industry and the company and meet the needs of passengers. Emotional work also requires a lot of physical resources. At the same time, because the flight attendant often encounters unpredictable problems such as irregular flights or unreasonable requests from passengers, they bring greater psychological pressure and is easy to produce negative emotion. However, colleges failed to set up reasonable training courses.

\subsection{Problems in General Professional Quality Training}

\subsubsection{Lack of Training Communication and Social Interpersonal Skills}

Communication and interpersonal skills have always been considered important professional qualities, but they are often overlooked in the training process. Communication and interpersonal skills cannot be improved only by theoretical teaching. On the one hand, less class hours cannot meet the training goals, on the other hand, communication skills assessment is quite difficult to deliver in spear time. As a result, a number of students encounter barriers when they need to talk to people.

\subsubsection{Insufficient Training of Teamwork Ability}

Teamwork is very important because tasks of the job need teamwork at all times. However, due to the family environment of the one-child family and the learning environment in colleges, the individual consciousness of college students has become stronger, which has caused female college students failed to interact with each other. Colleges have not provided reasonable channels for the cultivation of teamwork. 


\subsubsection{Ignore the Cultivation of Self-Discipline Consciousness}

Self-discipline is reflected in all aspects, whether you can strictly restrain yourself to work in accordance with the company's operating procedures; whether you can consciously manage your time; whether you can manage your own diet and maintaining an occupational image and abstaining from unhealthy living habits; they all require a strong sense of self-discipline. However, that students' self-discipline consciousness can only rely on themselves, because most colleges neglect the cultivation of it.

\subsection{Problems in Developmental Professional Quality Training}

\subsubsection{Insufficient Innovation Awareness and Ability}

At present, most colleges and universities have courses on innovation in talent training, but people's innovative consciousness and innovative ability cannot be achieved simply through classroom teaching. Most students are unable to innovate their way of thinking when they encounter problems.

\subsubsection{Weak Career Planning Awareness}

Career planning plays an important role in a person's career development process. The flight attendant profession has characteristics of younger age, short career, and blurred career development prospects. Women's careers are easily interrupted by factors such as marriage and childbirth. These problems require reasonable planning to boost the development of career. However, currently only a small number of female college students will consider their career development. They lack of long-term goal planning for career development.

\section{Strategies for Cultivating Professional Quality of Female College Students Majoring in Flight Attendants}

\subsection{Make Full Use of Curriculum Ideological and Political, Full-Staff Education and Other Ways to Improve Professional Moral Quality}

The improvement of professional moral quality should be constructed in all directions, and the pattern of full-staff, full-stage and full-course education should be realized in the process of talent training, and various courses should be in the same direction with ideological and political theory courses to form a synergistic effect. Teachers can make full use of the ideological and political forms of the curriculum, bring professional moral quality education in all courses, and integrate professional moral education through case study and other forms.

\subsection{Add Occupational Safety Education}

Occupational safety education should be regarded as a key point that cannot be ignored in vocational quality training, especially important for female college students. In the process of talent training, on the one hand, students should be familiar with operating norms during the work, and practice repeatedly to avoid safety accidents; on the other hand, workplace bullying and sexual harassment, which are more sensitive to female college students, even life threatening Criminal incidents should also be taught to students, such as how to protect and how to deal with correctly, so that students have the quality of calmly handling security incidents.

\subsection{Effectively Implement the Training of the Physical and Mental Quality}

The cultivation of physical and mental quality is a long-term and lasting training process. Students' spare time should be fully utilized, and the work content and physical and psychological characteristics of female college students should be fully considered. In terms of physical fitness training, daily training plans should be continuously carried out, at least 10-15 hours of physical training a week. At the same time, students are required to maintain correct emotion at work, such as smiling, and convert surface emotional work into deep emotional work while working. In terms of psychological quality training, we should focus on cultivating students how to cope with pressure, frustration, difficulties, etc., how to correctly release pressure and negative emotions, and adjust their mentality to ensure mental health.

\subsection{Design Teaching Methods Reasonably to Achieve Quality Education Goals}

Because traditional classroom teaching has obvious limitations in many quality trainings processes. In class time, teaching methods should be rationally designed to promote the achievement of quality training goals. For example, it is recommended that most courses can choose group teaching method. Every 6 people form a group to carry out teaching activities, and the group will be regularly reorganized, to cultivate students' teamwork. Some courses could pick case analysis, role-playing, and practical operations, so that students can learn by doing.

\subsection{Create an Integrated Professional Quality Training Mode}

The development of professional quality should be a long-term and lasting process, and the training goals cannot 
be achieved only through class time. Therefore, professional quality training should break the restrictions of the classroom, and make full use of various teaching stages and various training methods.

(1) Carry out daily assessment of professional quality in spare time

It is advisable to set up assessments for students' occupational image, etiquette, and physical training items in the working day's spare time, such as morning and evening hours each day, and regard the results as an important basis for the comprehensive evaluation of students. In this way, you can accelerate the formation of professional quality, and improve students' self-discipline awareness.

(2) Make full use of off-days to arrange social practice activities

Social practice activities are good opportunities to train the professional qualities comprehensively. When planning and selecting social practice activities, we should carefully choose activities related to professional work, such as conference and etiquette services, airport volunteer services, community services, etc. Through communicating with people, communication and social interpersonal competence can be cultivated. On the other hand, social practice allows students to get in touch with industry and society in advance, which can enhance students' sense of professional identity.

\subsection{Carry Out Full-Process Employment Guidance to Enhance the Awareness of Career Planning}

Career planning is a long-term plan with dynamic changes. Colleges can hire airline human resources experts to analyze and predict the students' professional development. They can also arrange tutors for students to help them formulate or modify career plans. Student can quantify the tasks in each stage of the plan, and checks the status quo of personal development at any time by means of balanced scorecards, etc., so that students can understand themselves and keep in mind the awareness of career planning.

\section{Conclusion}

By investigating the professional quality of female students majoring in flight attendants, it can be found that there are still many shortcomings in the training of professional quality. On the basis of research, this paper has formulated a system for the professional quality of female college students, and put forward suggestions for the training of professional quality, which could also be reference to colleges.

\section{References}

Gao, J.-Z. (2019). Research on the Basic Quality of Freshmen Majoring in Flight Attendants. Journal of Civil Aviation Flight University of China, 5, 39-41. (in Chinese)

Yang, H.-B., \& Xu, H.-J. (2010). Discussion on the problems and measures of college students' comprehensive quality evaluation. Modern Business Industry, (22), 103. (in Chinese)

Zhang, D. (2017). Analysis on the construction of the comprehensive quality evaluation system of the flight attendant college students. Human Resources Development, 3, 144-145. (in Chinese)

\section{Copyrights}

Copyright for this article is retained by the author(s), with first publication rights granted to the journal.

This is an open-access article distributed under the terms and conditions of the Creative Commons Attribution license (http://creativecommons.org/licenses/by/4.0/). 